\title{
Histidine requirement of kittens for growth, haematopoiesis and prevention of cataracts
}

\author{
BY DARCY D. QUAM, JAMES G. MORRIS* AND QUINTON R. ROGERS \\ Departments of Animal Science and Physiological Sciences, University of California, \\ Davis, California 95616, USA
}

(Received 11 May 1987 - Accepted 22 July 1987)

\begin{abstract}
1. The histidine requirement of growing kittens was determined from an experiment in which forty-eight kittens were randomly allocated to six amino acid-based diets supplying: $1 \cdot 0,1 \cdot 5,2 \cdot 0,2 \cdot 5,3.0$ or $4 \cdot 5 \mathrm{~g}$ histidine base $/ \mathrm{kg}$ diet.

2. By $48 \mathrm{~d}$ it was obvious that 1.0 and $1.5 \mathrm{~g}$ histidine/ $\mathrm{kg}$ diet were grossly inadequate so the kittens receiving these two diets were removed from the experiment. The other four groups of kittens continued to receive their diets for a total of $128 \mathrm{~d}$.

3. Mean daily weight gain, nitrogen retention and food intake attained plateau values at $2 \cdot 1 \mathrm{~g}$ histidine $/ \mathrm{kg}$ diet.

4. Blood samples taken at 25 and $48 \mathrm{~d}$ after kittens were given the diets showed a significant effect of dietary histidine on haemoglobin $(\mathrm{Hb})$ concentration. $\mathrm{Hb}$ and packed cell volume $(\mathrm{PCV})$ attained asymptotic values at $3.0 \mathrm{~g}$ histidine $/ \mathrm{kg}$ diet at $48 \mathrm{~d}$. At $128 \mathrm{~d}$, kittens consuming diets containing $2.0-4.5 \mathrm{~g}$ histidine $/ \mathrm{kg}$ had similar $\mathrm{Hb}$ and PCV values.

5. Cataracts of both eyes were observed in two of nine female kittens which had received diets containing either 2.0 or $2.5 \mathrm{~g}$ histidine $/ \mathrm{kg}$.

6. A concentration of $3 \mathrm{~g}$ histidine $/ \mathrm{kg}$ diet is recommended as a practical guide for feeding kittens.

7. There was a rectilinear relation $\left(r^{2} 0.99\right)$ between the logarithm of the histidine concentration of plasma and the concentration of histidine in the diet over the range $1.5-3.0 \mathrm{~g}$ histidine $/ \mathrm{kg}$ diet.
\end{abstract}

The essentiality of dietary histidine for the growing kitten was demonstrated by Rogers \& Morris (1979), who reported weight loss and depression of food intake in kittens whose diet was changed from one containing $9 \cdot 2 \mathrm{~g}$ histidine $/ \mathrm{kg}$ to one devoid of histidine. They further reported that weight gain was not affected when the histidine in the diet was reduced to $4.6 \mathrm{~g}$ histidine/ $\mathrm{kg}$ diet. Anderson et al. (1980) suggested that requirement for growth in kittens was approximately $3.0 \mathrm{~g}$ histidine $/ \mathrm{kg}$ diet. This estimate was based on the result of a single $4 \times 4$ Latin square experiment using kittens fed on $0.0,3.0,6.0$ and $9.9 \mathrm{~g}$ histidine/ $\mathrm{kg}$ diet for $9 \mathrm{~d}$ periods. Weight gain and food conversion efficiency were the only variables reported.

The protein haemoglobin $(\mathrm{Hb})$ is rich is histidine (Sebrell \& McDaniel, 1952) and may serve as an endogenous source of histidine, masking short-term deficits of the amino acid. The requirement of histidine for haematopoiesis in rats has been shown to be greater than that necessary for optimal weight gain (Nasset \& Gatewood, 1954). Therefore requirements based on weight gain over short periods of time may lead to an underestimate of the true requirement of growing animals.

The purpose of the present experiment was to define the histidine requirement of the growing kitten based on weight gain, food intake, nitrogen balance, haematological responses and general health. 


\section{METHODS}

\section{Animals}

Twenty-three female and twenty-five male specific-pathogen-free domestic short-hair kittens, weaned at 8 weeks of age and vaccinated against panleukopenia, were adapted to a basal amino acid diet (Tables 1 and 2). They were housed individually in stainless-steel metabolism $(0.6 \mathrm{~m} \times 0.5 \mathrm{~m} \times 0.8 \mathrm{~m})$ or holding $(0.3 \mathrm{~m} \times 0.5 \mathrm{~m} \times 0.8 \mathrm{~m})$ cages, with food and water available $a d$ lib. throughout the pre-feeding and experimental periods. Kittens were allocated to the experiment only if they readily consumed the basal diet and had growth rates of at least $15 \mathrm{~g} / \mathrm{d}$ for 1 week before the experiment. Mean (with SE) body-weights of male and female kittens at the start of feeding the experimental diets were 1180 (46) $\mathrm{g}$ and $1150(59) \mathrm{g}$ respectively.

\section{Diets}

Six experimental diets with varying levels of histidine $(1.0,1 \cdot 5,2 \cdot 0,2.5,3.0$ and $4.5 \mathrm{~g}$ histidine base $/ \mathrm{kg}$ diet) were tested. All essential amino acids other than histidine were included at levels adequate to support normal growth of the kitten and dispensable amino acids provided $\mathrm{N}$ in excess of the requirement. Alanine and starch were used to make the diets isonitrogenous and of similar composition except for the variable histidine levels used. Using determined energy digestibility coefficients of comparable diets and subtraction of the energy in the urea produced from catabolism of amino acids as a basis, the calculated metabolizable energy contents of the diets were $20.9 \mathrm{MJ} / \mathrm{kg}$. Sodium acetate was added to neutralize the hydrochlorides of lysine, arginine and histidine (Tables 1 and 2).

\section{Design}

Kittens were blocked on the basis of sex and randomly allocated to the six experimental diets, to give four kittens of each sex per treatment. However, because of a deficit in female kittens the $2.0 \mathrm{~g}$ histidine $/ \mathrm{kg}$ diet treatment had five male and three female kittens. While kittens were fed on the experimental diets daily food intake and body-weight were recorded.

Kittens in the dietary treatments 1.0 and $1.5 \mathrm{~g}$ histidine $/ \mathrm{kg}$ were removed from the experiment at day 48 , as it was apparent that these intakes of histidine were suboptimal and no additional information would be obtained by further subjection of the kittens to a deficient diet. Kittens on the other dietary treatments were continued for a further $80 \mathrm{~d}$ making a total experimental period of $128 \mathrm{~d}$. The experimental period for these groups was prolonged because a response to a dietary deficiency of histidine, in contrast to other essential amino acids, may be delayed. Hb contains a high concentration of histidine which in the normal course of erythrocyte breakdown can meet short-term deficiencies of this amino acid. The early studies of Rose et al. (1951) failed to show that histidine was an essential amino acid for humans due to the short (4-d) period the amino acid-free diet was given to the subjects.

Mean weight gain of each individual kitten was determined from a least squares linear regression of daily body-weight over a $16-\mathrm{d}$ period after the kittens had received the experimental diets for $12 \mathrm{~d}$, and were all housed for the entire period from the commencement of the experiment in the same type of individual holding cages. $\mathrm{N}$ balance was measured over a 7-d period during which the kittens were housed in stainless-steel metabolism cages measuring $0.6 \times 0.6 \times 0.8 \mathrm{~m}$. Balance measurements could not be made on all 48 kittens simultaneously because of limitation in the number of metabolism cages. $\mathrm{N}$ balance was measured separately on males and females after they had received the experimental diets for 28 and $39 \mathrm{~d}$ respectively. Urine, acidified with sulphuric acid, and 
Table 1. Composition of the supplemental diets $(\mathrm{g} / \mathrm{kg}$ diet $)$

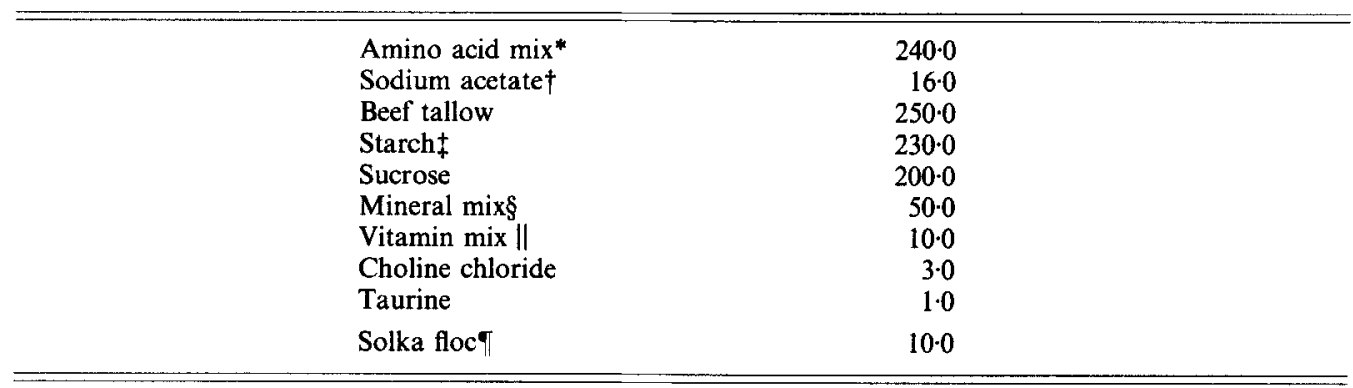

* For composition of amino acid mixtures, see Table 2.

$\dagger$ Adjusted to balance hydrochlorides in amino acid mixtures.

$\ddagger$ Melojel (food grade maize starch); National Starch and Chemical Company, Bridgewater, New Jersey.

$\S$ Mineral mix (g/kg mineral mix): $\mathrm{CaHPO}_{4} 390 \cdot 0, \mathrm{~K}_{2} \mathrm{HPO}_{4} 90 \cdot 0, \mathrm{CaCO}_{3} 110 \cdot 0, \mathrm{MgSO}_{4} 45 \cdot 0, \mathrm{KCl} 100 \cdot 0$, $\mathrm{KHCO}_{3} 100 \cdot 0, \mathrm{NaHCO}_{3} 140 \cdot 0, \mathrm{MnSO}_{4} \cdot \mathrm{H}_{2} \mathrm{O} 3 \cdot 84, \mathrm{ZnSO}_{4} .7 \mathrm{H}_{2} \mathrm{O} 4 \cdot 45, \mathrm{CuSO}_{4} .5 \mathrm{H}_{2} \mathrm{O} 0 \cdot 80, \mathrm{FeC}_{6} \mathrm{H}_{5} \mathrm{O}_{2} .3 \mathrm{H}_{2} \mathrm{O} 10 \cdot 0$, $\mathrm{Ca}_{5}\left(\mathrm{IO}_{6}\right)_{2} 0 \cdot 15, \mathrm{SnCl}_{2} \cdot 2 \mathrm{H}_{2} \mathrm{O} 0 \cdot 10, \mathrm{Na}_{2} \mathrm{SeO}_{3} 0 \cdot 03,\left(\mathrm{NH}_{4}\right)_{6} \mathrm{Mo}_{7} \mathrm{O}_{4} \cdot 4 \mathrm{H}_{2} \mathrm{O} 0 \cdot 04, \mathrm{CrCl}_{3} \cdot 6 \mathrm{H}_{2} \mathrm{O} 0 \cdot 26, \mathrm{NiCl}_{2} \cdot 6 \mathrm{H}_{2} \mathrm{O} 0 \cdot 30$, $\mathrm{NaF} 0 \cdot 14, \mathrm{NH}_{4} \mathrm{CO}_{3} .4 \mathrm{H}_{2} \mathrm{O} 0 \cdot 02, \mathrm{NaCl} 4 \cdot 87$.

II Contribution of vitamin mix (mg.kg diet): retinyl palmitate 11, cholecalciferol 0.05 , DL- $\alpha$-tocopheryl acetate 160 , menadione sodium bisulphite 14 , thiamin hydrochloride 25 , riboflavin 10 , pyridoxine hydrochloride 10 , nicotinic acid 100 , calcium pantothenate 20 , myo-inositol 200 , pteroylmonoglutamic acid 10 , cobalamin $0 \cdot 05$, Dbiotin 1, ascorbic acid 400 (as a preservative).

I Solka floc (wood cellulose); Brown Co., Berlin, New Hampshire; $10 \mathrm{~g}$ was added $/ \mathrm{kg}$ complete diet to facilitate faecal collection.

Table 2. Composition of amino acid mix for the $4.5 \mathrm{~g}$ histidine base $/ \mathrm{kg}$ diet

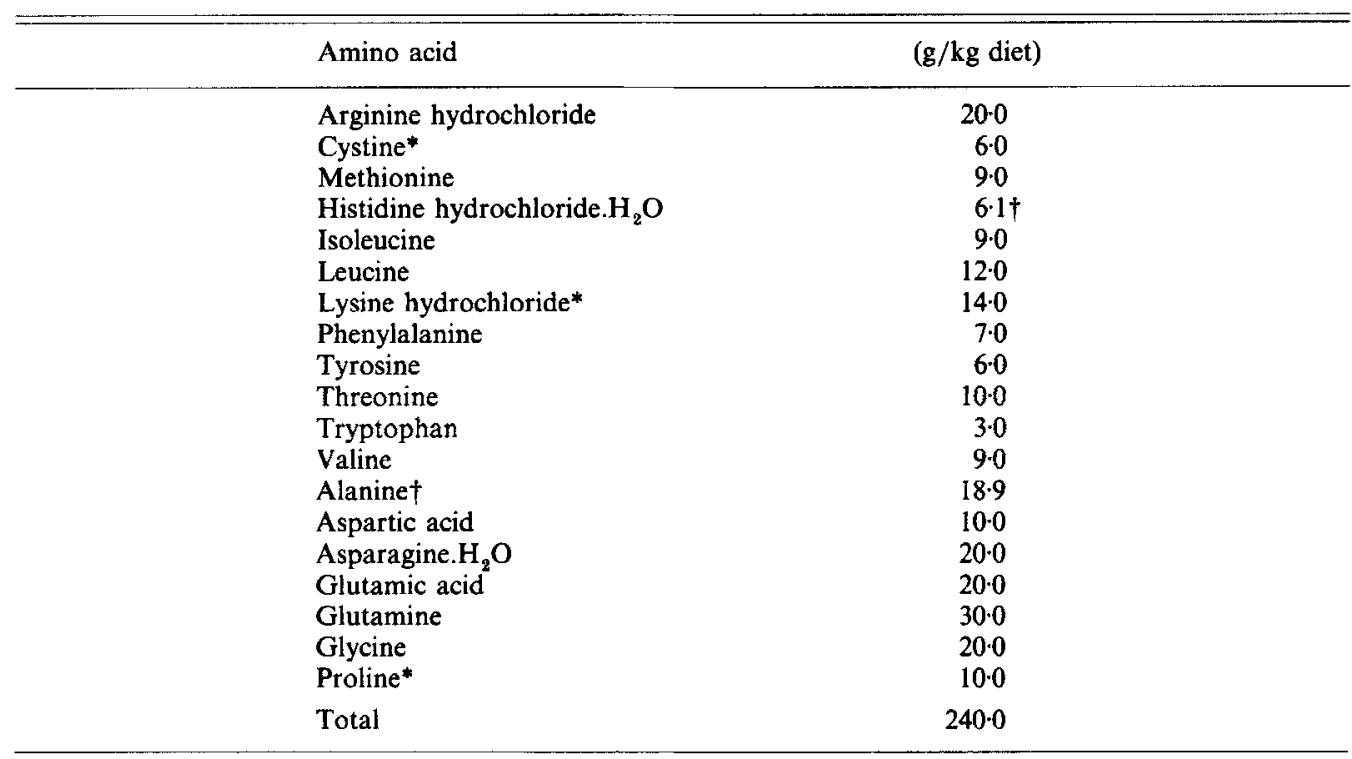

* Amino acids supplied by Sigma Chemical Co., St Louis, Missouri ; all other amino acids were supplied by Ajinomoto USA Inc., Los Angeles, California.

$†$ Experimental diets containing 3.0, 2.5, 2.0 and $1.5 \mathrm{~g}$ histidine base/ $\mathrm{kg}$ diet were prepared by blending two amino acid mixtures: the mixture above (for $4.5 \mathrm{~g}$ histidine base $/ \mathrm{kg}$ diet) and a similar one containing $1.356 \mathrm{~g}$ histidine hydrochloride. $\mathrm{H}_{2} \mathrm{O}(\mathrm{l} .0 \mathrm{~g}$ free base) $/ 240 \mathrm{~g}$ amino acid mixture. Alanine $(4.744 \mathrm{~g})$ was added to replace the histidine deleted in order that the proportions of other amino acids remained constant. Small additional amounts of alanine (maximum $1.32 \mathrm{~g} / \mathrm{kg}$ diet) were substituted for maize to maintain isonitrogenous diets as histidine contains a higher percentage of nitrogen than alanine. 
faeces were collected daily and pooled. $\mathrm{N}$ contents of feed, urine and faeces were measured by the Kjeldahl procedure (Association of Official Agricultural Chemists, 1975). Hair loss was examined and considered negligible for calculations.

\section{Blood analyses}

$\mathrm{Hb}$ concentration and packed cell volume (PCV) were measured on blood drawn every 3 weeks. Plasma-free histidine was measured at days 25 and 128 . Samples of blood $(3 \mathrm{ml})$ were taken from the jugular vein of unanaesthetized kittens in heparinized syringes at approximately the same time (11.00-13.00 hours) on each sampling day. Plasma was separated by centrifugation and stored along with a sample of whole blood for $\mathrm{Hb}$ determination using the cyanmethaemoglobin procedure (no. 525; Sigma Chemical Co., St Louis, Missouri). Samples of plasma were prepared for analysis of free amino acids by the addition of equal volumes of sulphosalicylic acid $(60 \mathrm{~g} / \mathrm{l})$, centrifuged to remove the protein precipitate, and filtrate adjusted to $\mathrm{pH} 2 \cdot 2$ with lithium hydroxide. An equivalent of $40 \mu \mathrm{l}$ plasma was applied to the amino acid analyser (Model 121MB; Beckman Instruments, Palo Alto, California). Plasma protein concentration was measured by use of a clinical refractometer.

\section{Statistical analysis}

Results were analysed by analysis of variance. Tukey's omega procedure was used to determine significant differences between treatment means (Steel \& Torrie, 1960). Values for males and females were analysed separately and combined. Some previous studies have shown significant differences between male and female kittens in daily weight gain, food intake and $\mathrm{N}$ retention (Schaeffer et al. 1982; Smalley et al. 1983; Hargrove et al. 1984) but not in requirements for essential amino acids or nitrogen. Because of the imbalance between the number of male and female kittens in the group receiving the diet containing $2 \mathrm{~g}$ histidine $/ \mathrm{kg}$, values for the male in the female block were adjusted for sex difference. To estimate the minimal requirements for growth and $\mathrm{N}$ balance, least-squares linear regressions were fitted to the ascending phase of the weight gain and $\mathrm{N}$ balance response relations to dietary histidine concentration. A line parallel to the $x$ axis was fitted to the mean of all points in the plateau portion of the response relation. The intersection of the two lines was used to indicate the minimal dietary requirement for maximal response. The criteria used to define points to be included in the plateau phase were: points should not be significantly different (i.e. $P>0.05$ ) from each other and once the response had been maximized all subsequent points were included in the plateau. The ascending phase regression included all points up to the first point of the plateau.

\section{RESULTS}

Kittens consuming the diets containing 1.0 and $1.5 \mathrm{~g}$ histidine $/ \mathrm{kg}$ diets had crusty exudates around their eyes and nostrils. These kittens exhibited a depression in food intake, retarded growth, emaciation and unkempt fur. One kitten given the $1.5 \mathrm{~g}$ histidine $/ \mathrm{kg}$ diet developed a Streptococcus canis infection during the 4 th week of the experiment. Although treatment with penicillin gave a rapid remission of clinical signs, values for this kitten were excluded for a 10-d period. At 1 month after the termination of the experiment, cataracts were observed in both eyes of two of nine females retained after the experiment for breeding purposes and given commercial cat chow. One of these two kittens had previously consumed the diet containing $2.0 \mathrm{~g}$ histidine $/ \mathrm{kg}$, the other (a sibling) the diet containing $2.5 \mathrm{~g}$ histidine $/ \mathrm{kg}$ diet. Of the remaining seven apparently normal kittens, four had previously consumed the $3.0 \mathrm{~g}$ histidine $/ \mathrm{kg}$ diet, two the $2.5 \mathrm{~g}$ histidine $/ \mathrm{kg}$ diet, and one the $2.0 \mathrm{~g}$ histidine $/ \mathrm{kg}$ diet. Ophthalmoscopic examinations of the cataracts revealed changes of the outer fibres of the lens, with no abnormalities of the retina. 


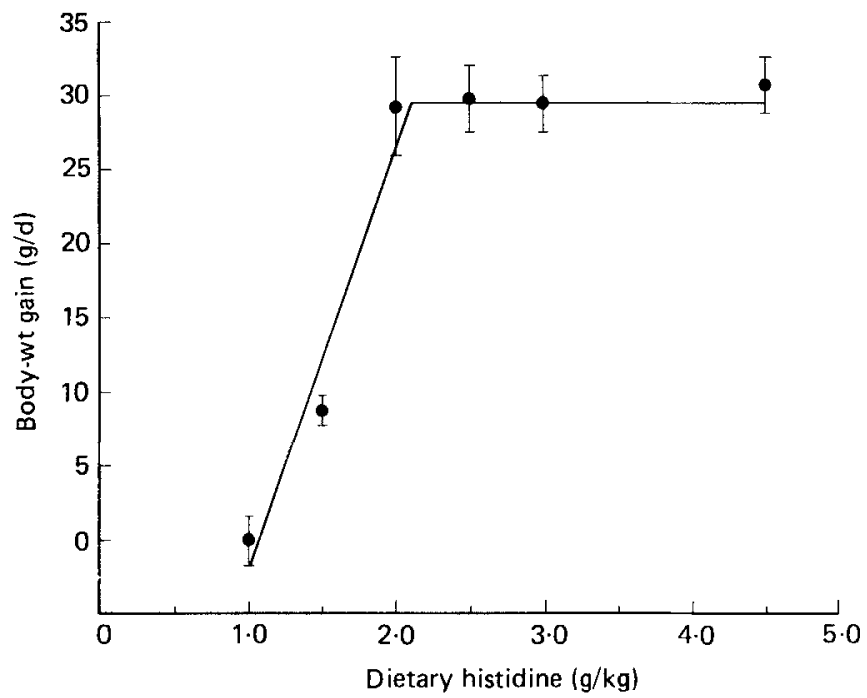

Fig. 1. The effect of dietary histidine on mean weight gain of kittens (combined sexes) for days 12 28 . Points are means with their standard errors represented by vertical bars for eight kittens.

Table 3. Effect of dietary histidine on body-weight gain, nitrogen retention and food conversion efficiency of kittens

(Mean values with their standard errors)

\begin{tabular}{|c|c|c|c|c|c|c|}
\hline \multirow[b]{2}{*}{ Sex } & \multirow{2}{*}{$\begin{array}{l}\text { Dietary } \\
\text { histidine } \\
(\mathrm{g} / \mathrm{kg})\end{array}$} & \multicolumn{2}{|c|}{$\begin{array}{l}\text { Weight gain* } \\
(\mathrm{g} / \mathrm{d})\end{array}$} & \multicolumn{2}{|c|}{$\begin{array}{l}\mathrm{N} \text { retention } \dagger \\
(\mathrm{g} \mathrm{N} / \mathrm{d})\end{array}$} & \multirow{2}{*}{$\begin{array}{c}\text { Food conversion } \\
\text { efficiency* } \\
\text { (g gain } / g \text { food } \\
\text { intake) }\end{array}$} \\
\hline & & Mean & $\mathrm{SE}$ & Mean & $\mathbf{S E}$ & \\
\hline Female & $\begin{array}{l}1 \cdot 0 \\
1 \cdot 5 \\
2 \cdot 0 \\
2 \cdot 5 \\
3 \cdot 0 \\
4 \cdot 5\end{array}$ & $\begin{array}{c}0 \cdot 7^{b} \\
10 \cdot 5^{b} \\
28 \cdot 0^{a} \\
29 \cdot 9^{a} \\
29 \cdot 3^{a} \\
26 \cdot 5^{a}\end{array}$ & $\begin{array}{l}1 \cdot 9 \\
1 \cdot 4 \\
2 \cdot 8 \\
3 \cdot 7 \\
2 \cdot 4 \\
0 \cdot 9\end{array}$ & $\begin{array}{l}0.22^{\mathrm{b}} \\
0.48^{\mathrm{a}, \mathrm{b}} \\
1 \cdot 10^{\mathrm{a}} \\
1.00^{\mathrm{a}} \\
0 \cdot 89^{\mathrm{a}} \\
0.80^{\mathrm{a}}\end{array}$ & $\begin{array}{l}0.13 \\
0.06 \\
0.32 \\
0.13 \\
0.15 \\
0.27\end{array}$ & $\begin{array}{l}0.02 \\
0.26 \\
0.41 \\
0.45 \\
0.41 \\
0.31\end{array}$ \\
\hline Male & $\begin{array}{l}1 \cdot 0 \\
1 \cdot 5 \\
2 \cdot 0 \\
2 \cdot 5 \\
3 \cdot 0 \\
4 \cdot 5\end{array}$ & $\begin{array}{r}-0.7^{\mathrm{b}} \\
7 \cdot 6^{\mathrm{b}} \\
29 \cdot 2^{\mathrm{a}} \\
29.8^{\mathrm{a}} \\
29 \cdot 2^{\mathrm{a}} \\
34 \cdot 7^{\mathrm{a}}\end{array}$ & $\begin{array}{l}2 \cdot 7 \\
0.7 \\
5 \cdot 2 \\
2 \cdot 9 \\
2.9 \\
2 \cdot 5\end{array}$ & $\begin{array}{l}0.23^{\mathrm{b}} \\
0.35^{\mathrm{b}} \\
1.37^{\mathrm{a}} \\
1.46^{\mathrm{a}} \\
1.56^{\mathrm{a}} \\
1.70^{\mathrm{a}}\end{array}$ & $\begin{array}{l}0.03 \\
0-03 \\
0.18 \\
0.22 \\
0.17 \\
0.30\end{array}$ & $\begin{array}{r}-0.02 \\
0.19 \\
0.36 \\
0.38 \\
0 \cdot 40 \\
0.44\end{array}$ \\
\hline
\end{tabular}

a,b Values within the same column and sex grouping not sharing a common superscript letter were significantly different $(P<0-05)$.

* For a 16-d period commencing on day 13.

$\uparrow 7-d$ period commencing on day 28 for males and day 39 for females.

\section{Weight gain}

Mean (with SE) daily weight gains for the combined values of male and female kittens in six dietary treatment groups over a $16 \mathrm{~d}$ period are given in Fig. 1 and Table 3. Daily weight gains for both sexes individually and combined (Table 3$)$ were significantly less $(P<0.05)$ for kittens receiving diets containing 1.0 and $1.5 \mathrm{~g}$ histidine $/ \mathrm{kg}$ than for kittens given higher levels of histidine. Mean daily weight gains of kittens given diets containing $2 \cdot 0,2 \cdot 5,3 \cdot 0$ and $4.5 \mathrm{~g}$ histidine $/ \mathrm{kg}$ were not significantly different from one another for either sex. No 
significant difference occurred in the weight gain of kittens receiving these diets over the last $80 \mathrm{~d}$ of the experiment. Therefore, analysis of variance indicated a minimal requirement of $2.0 \mathrm{~g}$ histidine $/ \mathrm{kg}$ diet. The intersection of the least-squares linear regression fitted to the ascending phase of the weight gain response relation to dietary histidine concentration and the line parallel to the $x$ axis (fitted to the mean of all points not included in the ascending phase) occurred at $2 \cdot 1 \mathrm{~g}$ histidine $/ \mathrm{kg}$ diet. Male kittens had a slightly, but not significantly, higher daily body-weight gain than females. Means (with SE) for kittens given the diets containing $2.0-4.5 \mathrm{~g}$ histidine $/ \mathrm{kg}$ were $30.7(1.2) \mathrm{g} / \mathrm{d}$ for males and $28.4(0.7) \mathrm{g} / \mathrm{d}$ for females, and $29 \cdot 6(0 \cdot 3) \mathrm{g} / \mathrm{d}$ for the combined sexes.

\section{$N$ balance}

$\mathrm{N}$ balance results corroborated a requirement of about $2.0 \mathrm{~g}$ histidine $/ \mathrm{kg}$ diet based on the growth estimates. Values for $\mathrm{N}$ retention for the combined sexes given diets containing $1 \cdot 0$ and $1.5 \mathrm{~g}$ histidine $/ \mathrm{kg}$ were significantly less $(P<0.05)$ than $\mathrm{N}$ retention for histidine intakes of $2.0 \mathrm{~g} / \mathrm{kg}$ or greater. $\mathrm{N}$ retention for both sexes was not significantly different for diets containing $2 \cdot 0-4.5 \mathrm{~g}$ histidine $/ \mathrm{kg}$ (Table 3 ). The combined male and female $\mathrm{N}$ retention response curve (Fig. 2) shows a linear increase in retention with each increment of dietary histidine from 1.0 to $2.0 \mathrm{~g}$ histidine $/ \mathrm{kg}$ dietary levels. At $2.0 \mathrm{~g}$ histidine $/ \mathrm{kg}$ diet, $\mathrm{N}$ retention attained an asymptotic value of 1.24 (SE 0.06$) \mathrm{g} \mathrm{N} / \mathrm{d}$.

\section{Food intake}

The effect of dietary histidine concentration on the combined food intake of male and female kittens is shown for the three consecutive weekly periods in Fig. 3. Kittens given diets containing 1.0 and $1.5 \mathrm{~g}$ histidine $/ \mathrm{kg}$ had significantly lower $(P<0.05)$ food intakes at each time interval. The males showed a greater response to increasing histidine concentration than the females, presumably because of their slightly greater growth rate. However, both sexes by the third period (26-33 d) showed significantly lower food intake for the diets containing 1.0 and $1.5 \mathrm{~g}$ histidine $/ \mathrm{kg}$ than at higher levels of histidine. As the duration of the experimental increased, food intake decreased for the 1.0 and $1.5 \mathrm{~g}$ histidine/ $\mathrm{g}$ diets, while all higher treatment levels exhibited an increase in food intake over time. The food intake of both sexes combined attained maximal values at a dietary histidine level of $2.0 \mathrm{~g} / \mathrm{kg}$ diet. Food conversion efficiency was not significantly different for treatments $2.0-4.5 \mathrm{~g}$ histidine $/ \mathrm{kg}$ diet (mean 0.40 (SE 0.05 ) $\mathrm{g}$ body-weight gain $/ \mathrm{g}$ food intake). However, for groups receiving 1.0 and $1.5 \mathrm{~g}$ histidine $/ \mathrm{kg}$ diet the mean food conversion efficiency was $0 \cdot 11$ (SE 0.13) $\mathrm{g}$ body-weight gain/g food intake.

\section{Plasma proteins}

Plasma protein concentrations were measured on days 25 and 128 . There were no significant treatment or sex effects at either time-point and plasma protein concentrations were within the normal range for the kitten.

\section{Plasma-free histidine}

Histidine concentration of the kittens' plasma at day 25 is shown in Fig. 4. Concentrations of histidine in plasma from both male and female kittens given diets containing 1.0 and $1.5 \mathrm{~g}$ histidine $/ \mathrm{kg}$ were significantly lower $(P<0.05)$ than those in kittens given diets containing 3.0 and $4.5 \mathrm{~g}$ histidine $/ \mathrm{kg}$. The intermediary dietary levels of histidine resulted in plasma concentrations which were not significantly different from kittens receiving either the 3.0 .4 .5 or $1.0-1.5 \mathrm{~g}$ histidine $/ \mathrm{kg}$ diet levels. Fig. 5 shows a plot of the logarithim of the mean combined sex plasma concentration of histidine $v$. histidine concentration in the diet. 


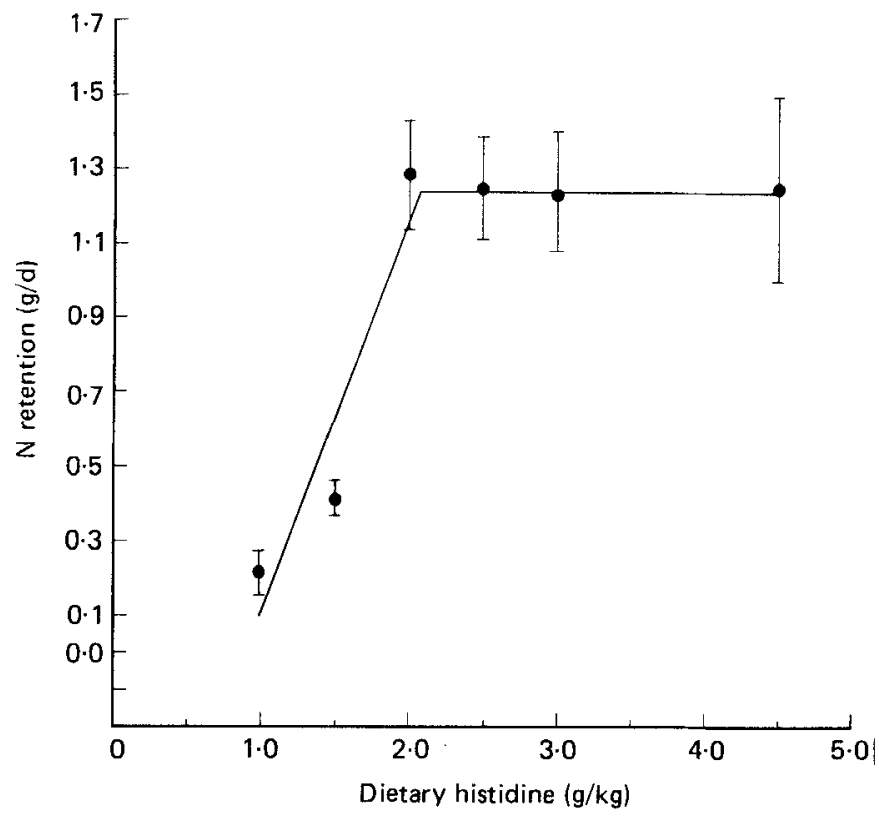

Fig. 2. The effect of dietary histidine on nitrogen retention of kittens (combined sexes). Points are mean values with their standard errors represented by vertical bars for eight kittens. $\mathrm{N}$ retention was measured over 7- $d$ periods commencing after the diets containing variable levels of histidine had been fed for $28 \mathrm{~d}$ for males and $39 \mathrm{~d}$ for females.

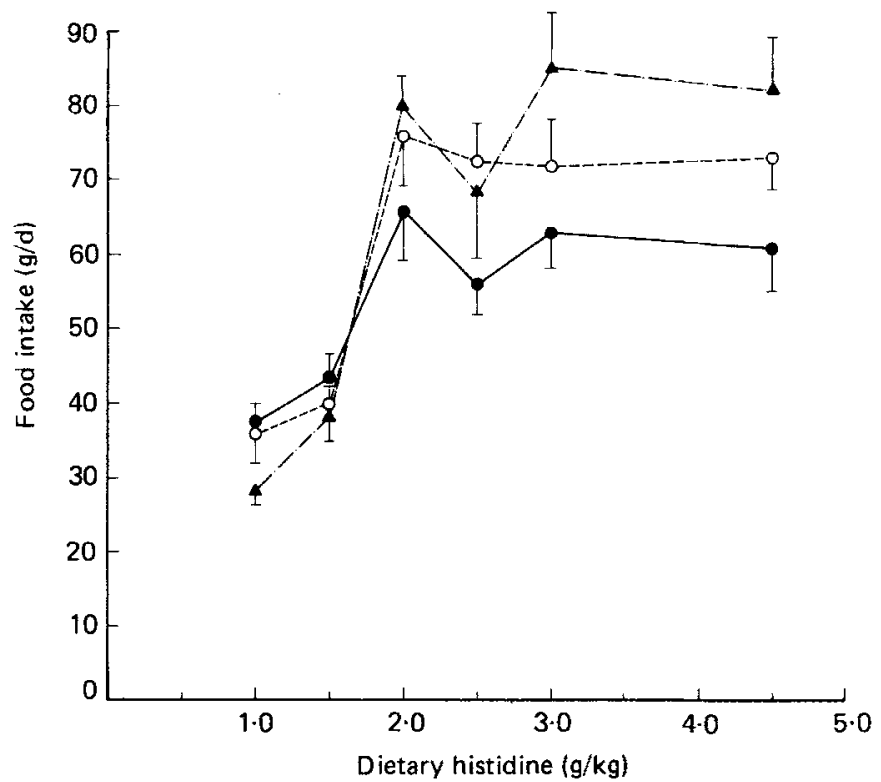

Fig. 3. The effect of dietary histidine on daily food intake of kittens (combined sexes) for three consecutive periods: $(\mathbf{O})$, days $10-17 ;\left(\mathrm{O}_{--} \mathrm{O}\right)$, days $18-25 ;\left(\mathbf{A}^{-\cdot-\mathbf{A}}\right)$, days 26-33. Points are mean values with their standard errors represented by vertical bars for eight kittens. 


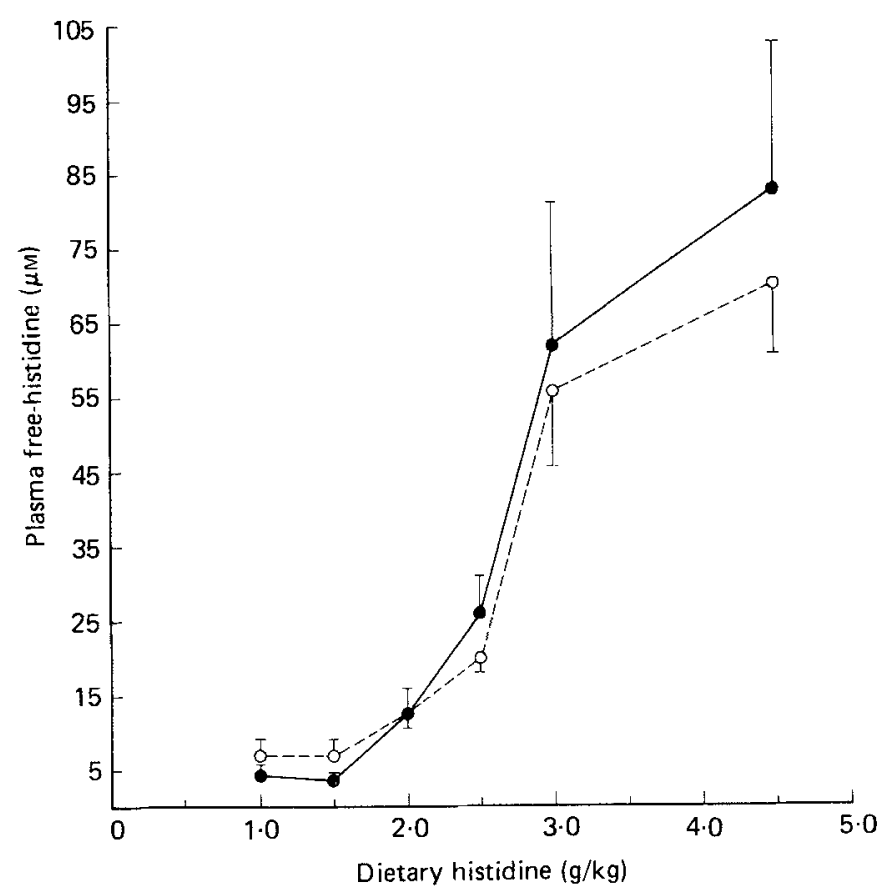

Fig. 4. The effect of dietary histidine concentration on plasma-free histidine of male $(O)$ and female $(O)$ kittens on day 25. Points are mean values with their standard errors represented by vertical bars for four kittens.

Two linear regressions were fitted, one for the range $1 \cdot 0-3 \cdot 0 \mathrm{~g}$ histidine $/ \mathrm{kg}$ diet and the other for $1 \cdot 5-3.0 \mathrm{~g}$ histidine $/ \mathrm{kg}$ diet. The two equations were as follows:

$$
\begin{gathered}
y_{1}=0.112+0.52 x, r^{2} 0.90, \\
y_{2}=-0.307+0.688 x, r^{2} 0.995,
\end{gathered}
$$

where $y_{1}$ and $y_{2}$ are histidine concentrations in plasma $(\mu \mathrm{M})$ for the dietary concentrations of histidine $(x)$ of $1.0-3.0$ and $1.5-3.0 \mathrm{~g} / \mathrm{kg}$ diet respectively. Also plotted in Fig. 5 are the concentrations of histidine in plasma on day 128 which follow a similar pattern to day 25 , except the values for the two lowest concentrations $(1.0$ and $1.5 \mathrm{~g}$ histidine $/ \mathrm{kg}$ diet $)$ are absent.

On both days 25 and 128 an apparent maximal plasma concentration of histidine occurred at a dietary level of $3 \mathrm{~g}$ histidine $/ \mathrm{kg}$ diet. Therefore it appears that a break point occurs at this dietary concentration.

\section{$\mathrm{Hb}$ and $\mathrm{PCV}$}

$\mathrm{Hb}$ values for days 25, 48 and 128 are shown in Table 4. Although significant differences $(P<0.05)$ in $\mathrm{Hb}$ concentration were only found between some treatments $(1.5 v .3 .0$ and $4.5 \mathrm{~g}$ histidine $/ \mathrm{kg}$ diet for females at days 25 and 48 , and for the 1.0 and $1.5 v .4 .5 \mathrm{~g}$ histidine/ $\mathrm{kg}$ treatments for males at day 48), there was a general positive relation over the range $1.5-3.0 \mathrm{~g}$ histidine/ $\mathrm{kg}$ diet between $\mathrm{Hb}$ concentration and dietary histidine (Fig. 6). Analysis of combined sex values for days 25 and 48 showed an apparent plateau at 3.0 histidine $/ \mathrm{kg}$ diet at days 25 and 48 with no further increase at $4.5 \mathrm{~g}$ histidine $/ \mathrm{kg}$ diet. However, by day 128 the $\mathrm{Hb}$ concentrations of the blood from kittens consuming diets containing $2 \cdot 0-4 \cdot 5 \mathrm{~g}$ histidine $/ \mathrm{kg}$ were not significantly different. 


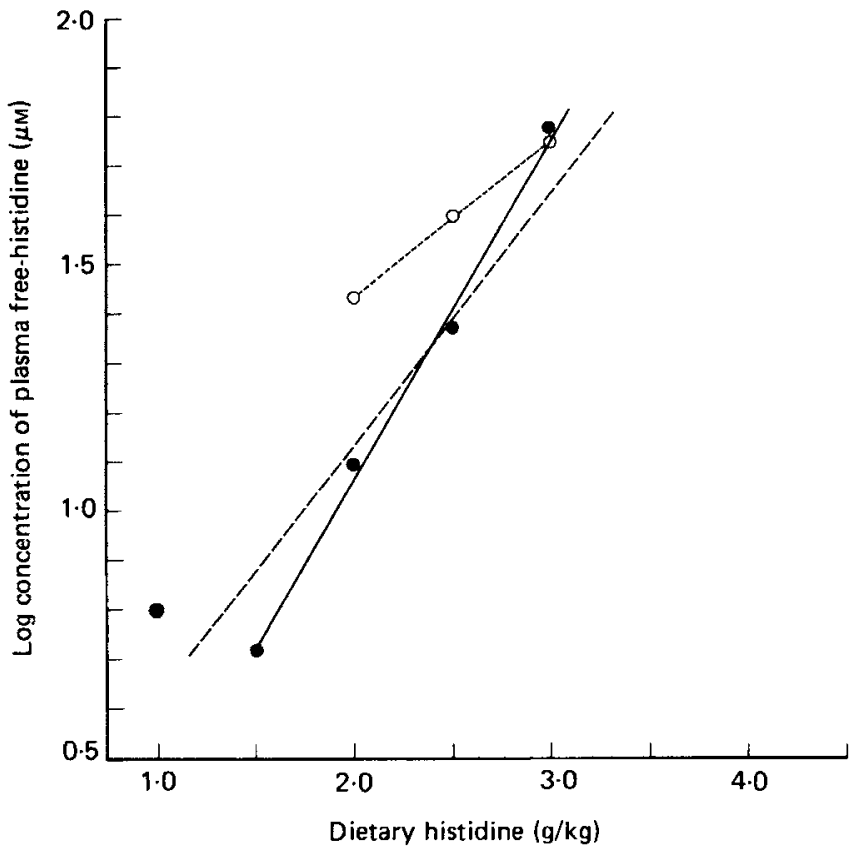

Fig. 5. Logarithm of the mean concentration (combined sexes) of free histidine in plasma of kittens in relation to the concentration of histidine in the diet on day $25(O)$ and day $128(O)$. Regressions of mean plasma concentrations from kittens given diets containing $1.0-3.0$ and $1.5-3.0 \mathrm{~g}$ histidine $/ \mathrm{kg}$ diet are shown as -..- and respectively.

Table 4. Effect of dietary histidine on haemoglobin concentration in blood of kittens on days 25,48 and 128

(Mean values with their standard errors)

\begin{tabular}{|c|c|c|c|c|c|c|c|}
\hline \multirow[b]{3}{*}{ Sex } & \multirow{3}{*}{$\begin{array}{l}\text { Dietary } \\
\text { histidine } \\
(\mathrm{g} / \mathrm{kg})\end{array}$} & \multicolumn{6}{|c|}{ Haemoglobin ( $\mathrm{g} / \mathrm{l}$ blood) } \\
\hline & & \multicolumn{2}{|c|}{ Day 25} & \multicolumn{2}{|c|}{ Day 48} & \multicolumn{2}{|c|}{ Day 128} \\
\hline & & Mean & SE & Mean & SE & Mean & SE \\
\hline Female & $\begin{array}{l}1.0 \\
1.5 \\
2.0 \\
2.5 \\
3.0 \\
4.5\end{array}$ & $\begin{array}{c}93^{\mathrm{a}, \mathrm{b}} \\
87^{\mathrm{b}} \\
93^{\mathrm{a}, \mathrm{b}} \\
101^{\mathrm{a}, \mathrm{b}} \\
108^{\mathrm{a}} \\
103^{\mathrm{a}}\end{array}$ & $\begin{array}{l}5 \\
6 \\
4 \\
4 \\
3 \\
3\end{array}$ & $\begin{array}{c}92^{\mathrm{a}, \mathrm{b}} \\
84^{\mathrm{b}} \\
104^{\mathrm{a}, \mathrm{b}} \\
109^{\mathrm{a}} \\
114^{\mathrm{a}} \\
115^{\mathrm{a}}\end{array}$ & $\begin{array}{l}5 \\
5 \\
2 \\
7 \\
7 \\
5\end{array}$ & $\begin{array}{l}- \\
\overline{110^{\mathrm{a}}} \\
110^{\mathrm{a}} \\
114^{\mathrm{a}} \\
117^{\mathrm{a}}\end{array}$ & $\begin{array}{l}- \\
- \\
2 \\
2 \\
9 \\
5\end{array}$ \\
\hline Male & $\begin{array}{l}1.0 \\
1.5 \\
2.0 \\
2.5 \\
3.0 \\
4.5\end{array}$ & $\begin{array}{r}90^{\mathrm{a}} \\
92^{\mathrm{a}} \\
98^{\mathrm{a}} \\
95^{\mathrm{a}} \\
104^{\mathrm{a}} \\
104^{\mathrm{a}}\end{array}$ & $\begin{array}{l}3 \\
5 \\
3 \\
5 \\
4 \\
1\end{array}$ & $\begin{array}{c}89^{\mathrm{b}} \\
88^{\mathrm{b}} \\
97^{\mathrm{a}, \mathrm{b}} \\
99^{\mathrm{a}, \mathrm{b}} \\
102^{\mathrm{a}, \mathrm{b}} \\
113^{\mathrm{a}}\end{array}$ & $\begin{array}{l}2 \\
2 \\
3 \\
1 \\
3 \\
4\end{array}$ & $\begin{array}{c}- \\
\overline{110^{\mathrm{a}}} \\
111^{\mathrm{a}} \\
115^{\mathrm{a}} \\
114^{\mathrm{a}}\end{array}$ & $\begin{array}{l}- \\
4 \\
4 \\
8 \\
4\end{array}$ \\
\hline
\end{tabular}

a,b Values within the same column and sex grouping not sharing a common superscript letter were significantly different $(P>0.05)$. 


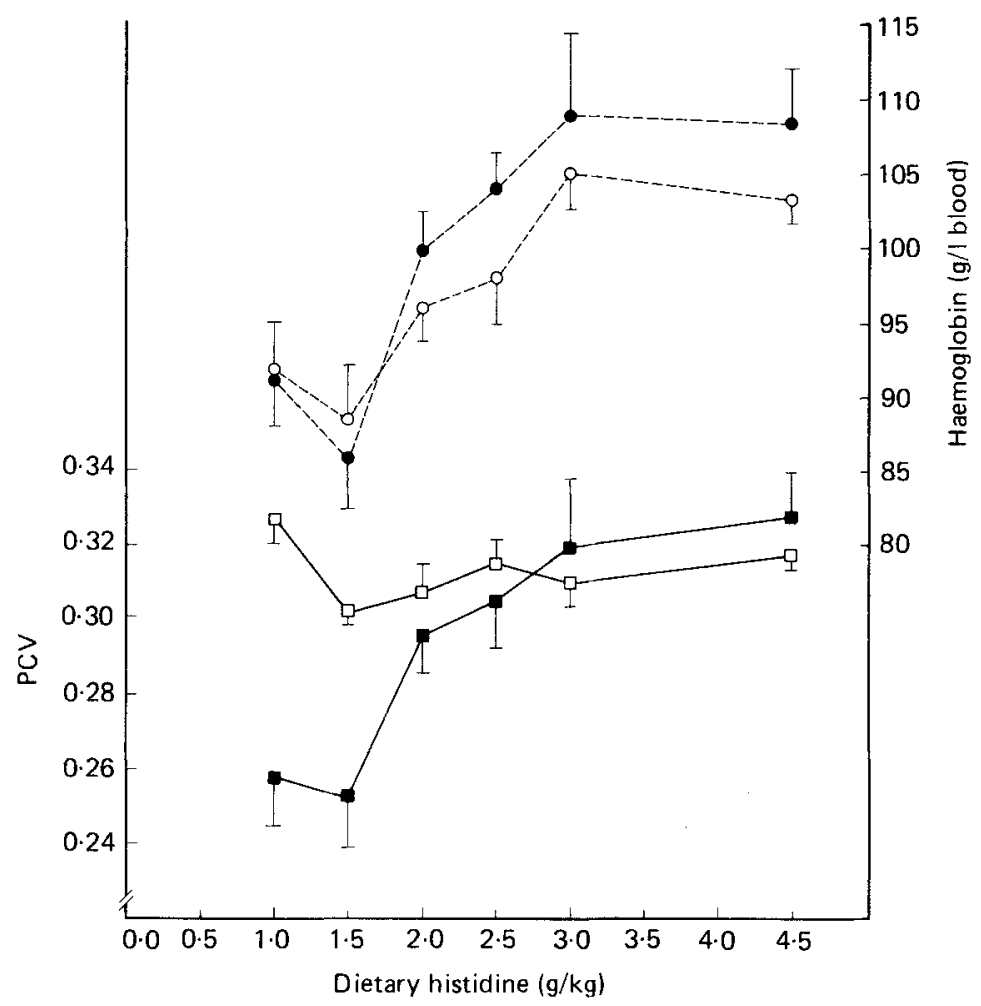

Fig. 6. The effect of dietary histidine on haemoglobin concentration $(0,0)$ and packed cell volume (PCV; $\square, \square$ ) of the blood of kittens on days $25(\mathrm{O}, \square)$ and $48(\mathbf{O}, \boldsymbol{\square})$. Points are mean values with their standard errors represented by vertical bars.

PCV for days 25 and 48 are also presented in Fig. 6. At day 25 there were no significant differences $(P<0.05)$ as a result of sex or histidine treatments. Also, there was no apparent overall relation between dietary histidine and PCV. However, combined sex values for day 48 showed a positive relation between PCV of kittens consuming the diets containing 1.0 and $1.5 \mathrm{~g}$ histidine $/ \mathrm{kg}$ and that of those consuming the diets containing 3.0 and $4.5 \mathrm{~g}$ histidine/kg. PCV for kittens consuming intermediate dietary histidine levels were not significantly different from either the higher or lower levels. The response of $\mathrm{Hb}$ and PCV to dietary histidine at day 48 indicates a higher requirement $(3 \cdot 0$ histidine $/ \mathrm{kg}$ diet $)$ than that needed to maximize growth. At day 128 this response was no longer evident which suggested that $2.0 \mathrm{~g}$ histidine $/ \mathrm{kg}$ diet would be adequate for adult cats for haematopoiesis.

\section{DISCUSSION}

Analysis of response values for daily weight gain, $\mathrm{N}$ retention and food intake of the growing kitten, by both statistical and graphical methods, gave a consistent minimal value for the histidine requirement of about $2.0 \mathrm{~g}$ histidine $/ \mathrm{kg}$ diet. These three variables for both males and females individually and combined increased rectilinearly with increasing dietary histidine, until the plateau value of about $2.0 \mathrm{~g}$ histidine $/ \mathrm{kg}$ diet was attained. The requirement suggested by Anderson et al. (1980) based on only weight gain and food conversion efficiency was $3.0 \mathrm{~g}$ histidine $/ \mathrm{kg}$ diet. However, as Anderson et al. (1980) used increments of $3.0 \mathrm{~g}$ histidine $/ \mathrm{kg}$ diet, their estimate could only be regarded as a crude approximation. 
Histidine requirements reported for other species based on weight gain, plasma-free histidine and food conversion efficiency, are comparable to the value indicated here. Histidine requirements reported for the immature dog (Burns \& Milner, 1982), the weanling pig (Rechcigl et al. 1956) and the mouse ((US) National Research Council, 1978) are similar to our estimate for the kitten based on weight gain alone. Robbins et al. (1977) reported that the chick has a slightly higher requirement of $3.0 \mathrm{~g}$ histidine $/ \mathrm{kg}$ diet.

In the present study, the concentration of histidine in plasma rose quite sharply after the dietary intakes of histidine exceeded that required to maximize weight gain, $\mathrm{N}$ retention and food intake. Similarly, Robbins et al. (1977) reported that maximal weight gain in the chick also occurred before elevation of plasma histidine. Kopple \& Swendseid (1981) found histidine concentration of plasma from humans was not well correlated with dietary intake, and hence of limited value in estimating a requirement. Mitchell et al. (1968) also reported a lower estimate of the histidine requirement from weight gain in pigs than that indicated by breakpoint analysis of histidine concentration in plasma. However, for our values from growing kittens when the logarithm of histidine concentration in plasma was plotted $v$. histidine in the diet, a sharp change of slope occurred at $3 \mathrm{~g}$ histidine $/ \mathrm{kg}$ diet. It is tempting to suggest that there may be a functional relation between this concentration in plasma and maintenance of normal integrity of the eye.

$\mathrm{Hb}$ and PCV were used by Nasset \& Gatewood (1954) as indices for estimating the histidine requirement of rats. They reported a requirement of $2.5 \mathrm{~g}$ histidine $/ \mathrm{kg}$ diet for maximal erythropoiesis, which was higher than the estimate of McLaughlan \& Illman (1967) of $2.0 \mathrm{~g}$ histidine $/ \mathrm{kg}$ diet based on weight gain. Hb concentration of blood and PCV have been reported to be decreased in histidine deficiency in humans (Kopple \& Swendseid, 1975), rats (Quinn \& Fisher, 1977) and dogs (Burns \& Milner, 1982). However, Snyderman et al. (1963) reported no change in either $\mathrm{Hb}$ or PCV in short-term studies with histidinedeficient infants. In our study, $\mathrm{Hb}$ and $\mathrm{PCV}$ values were depressed when the diet contained histidine concentrations lower than $1.5 \mathrm{~g} / \mathrm{kg}$. Hb concentration at both days 25 and 48 attained plateau values in kittens consuming the $3.0 \mathrm{~g}$ histidine $/ \mathrm{kg}$ diet, although values for kittens on the 2.0 and $2.5 \mathrm{~g}$ histidine $/ \mathrm{kg}$ dietary treatments were not significantly different. Similarly, at day $48 \mathrm{PCV}$ attained a plateau in kittens receiving $3.0 \mathrm{~g}$ histidine $/ \mathrm{kg}$ diet. A plateau was not demonstrable at day 128 for treatments ranging from 2.0 to $4.5 \mathrm{~g}$ histidine/ $\mathrm{kg}$, suggesting that more mature cats have a lower requirement for histidine for erythropoiesis than the growing kitten.

Plasma protein concentrations were not affected by dietary histidine in the present study, which is consistent with the findings of Easter \& Baker (1977) for pigs. However, Kopple \& Swendseid (1981) reported for humans, and Cianciaruso et al. (1981) reported for dogs, a marked reduction in plasma protein concentrations with histidine deficiency. Part of the apparent inconsistency may be due to relative differences in the range of dietary concentrations used and their effects on growth and expansion of the plasma volume.

The presence of cataracts in two sibling cats which had previously consumed the diets containing 2.0 and $2.5 \mathrm{~g}$ histidine $/ \mathrm{kg}$ must also be considered in determining a requirement. Maun et al. (1946) and Hall et al. (1948) reported cataract formation in rats consuming a histidine-free diet. Pathological changes included a clouding of lens substance followed by an apparent granular disintegration of the more superficial fibres within 10-34 d of consuming a histidine-free diet. In comparison, the two cats which developed cataracts in our study were not observed on gross inspection to have abnormalities until 1 month after the end of the experiment. Ophthalmological examination at this time revealed changes in the outer fibres of the lens and normal retinas. The probability that this condition is due to a congenital abnormality or the subsequent commercial diet is remote, as cataracts have not been observed in eight generations of cats at this colony given commercial diets. Although maximal weight gain and $\mathrm{N}$ retention occurred at about $2 \cdot 0 \mathrm{~g}$ histidine $/ \mathrm{kg}$ diet, 
$\mathrm{Hb}, \mathrm{PCV}$, plasma concentration of histidine and the occurrence of cataracts suggest that the young kitten requires $3.0 \mathrm{~g}$ histidine $/ \mathrm{kg}$ diet for erythropoiesis and normal lens fibre growth. The requirement may decrease to about $2.0 \mathrm{~g}$ histidine $/ \mathrm{kg}$ for the adult cat. Because of the relatively slow response time of $\mathrm{Hb}$ and PCV to dietary histidine intake, it is apparent that Latin-square designs similar to those we have used to investigate the requirement for other amino acids (e.g. Hargrove et al. 1983; Smalley et al. 1983) are inappropriate for histidine. Furthermore, the histidine requirement appears to be related to age or rate of haematopoiesis and is greater in young kittens than older cats. The dietary requirement of histidine depends on the physiological function measured and it is interesting to note that the proposed dietary level is about 1.5 times the requirement for maximal growth or $\mathrm{N}$ balance.

Thanks are due to Dr Leigh West for ophthalmological examinations and veterinary advice and to Dan Wong for assistance with plasma amino acid analyses. This research was supported in part by funding from the Pet Food Institute, Washington, DC. The vitamins and choline chloride were gifts from Hoffman-La Roche Inc., Nutley, New Jersey 07110, and International Minerals and Chemical Corp., Terre Haute, Indiana 47808 respectively.

\section{REFERENCES}

Anderson, P. A., Baker, D. H., Sherry, P. A. \& Corbin, J. E. (1980). Journal of Animal Science 50, $479-483$. Association of Official Agricultural Chemists. (1975). Official Methods of Analysis, 12th edn. Washington, DC: Association of Official Agricultural Chemists.

Burns, R. A. \& Milner, J. A. (1982). Journal of Nutrition 112, 447-452.

Cianciaruso, B., Jones, M. R. \& Kopple, J. D. (1981). Journal of Nutrition 111, $1074-1084$.

Easter, R. A. \& Baker, D. H. (1977). Journal of Nutrition 107, 120-125.

Hall, W. K., Bowles, L. L., Syndenstricker, V. P. \& Schmidt, H. L. (1948). Journal of Nutrition 36, $277-295$.

Hargrove, D. M., Rogers, Q. R. \& Morris, J. G. (1983). British Journal of Nutrition 50, 487-493.

Hargrove, D. M., Rogers, Q. R. \& Morris, J. G. (1984). British Journal of Nutrition 52, 595-605.

Kopple, J. D. \& Swendseid, M. E. (1975). Journal of Clinical Investigation 55, 881-891.

Kopple, J. D. \& Swendseid, M. E. (1981). Journal of Nutrition 111, 931-942.

McLaughlan, J. M. \& Illman, W. I. (1967). Journal of Nutrition 93, 21-24.

Maun, M. E., Cahill, W. M. \& Davis, R. M. (1946). Archives of Pathology 41, $25-31$.

Mitchell, J. R., Becker D. E., Jensen, A. H., Harmon, B. G. \& Norton, H. W. (1968). Journal of Animal Science 27, 1327-1331.

Nasset, E. S. \& Gatewood, V. H. (1954). Journal of Nutrition 53, 163-176.

National Research Council (1978). Nutrient Requirements of Domestic Animals no. 10, Nutrient Requirements of Laboratory Animals, 3rd edn. Washington, DC: National Academy of Sciences.

Quinn, M. R. \& Fisher, H. (1977). Journal of Nutrition 107, 2044-2054.

Rechcigl, M., Loosli, J. K., Horvath, D. J. \& Williams, H. H. (1956). Journal of Nutrition 60, 619-629.

Robbins, K. R., Baker, D. H. \& Norton, H. W. (1977). Journal of Nutrition 107, 2055-2061.

Rogers, Q. R. \& Morris, J. G. (1979). Journal of Nutrition 109, 718-723.

Rose, W. C., Haines, W. J., Warner, D. T. \& Johnson, J. E. (1951). Journal of Biological Chemistry 188, 49-58.

Schaeffer, M. C., Rogers, Q. R. \& Morris, J. G. (1982). Journal of Nutrition 112, 962-971.

Sebrell, W. H. \& McDaniel, E. G. (1952). Journal of Nutrition 47, 477-486.

Smalley, K. A., Rogers, Q. R. \& Morris, J. G. (1983). British Journal of Nutrition 49, 411-417.

Snyderman, S. E., Boyer, A., Roitman, E., Holt, L. E. \& Prose, P. H. (1963). Pediatrics 31, 786-801.

Steel, R. G. \& Torrie, J. H. (1960). The Principles and Procedures of Statistics. New York: McGraw-Hill. 